\title{
DUAL MONETARY SYSTEM AND MACROECONOMIC PERFORMANCE IN INDONESIA
}

\author{
Sri Herianingrum, Imronjana Syapriatama
}

\begin{abstract}
Dual Monetary System and Macroeconomic Performance in Indonesia. This research aims to evaluate the impact of dual monetary policy shock on macroeconomic indicators of Indonesia: growth and inflation. In addition, this study will also examine whether conventional monetary policy has a particular impact upon Islamic banking sector. This research apply VAR (vector auto regressive) method on monthly data from Bank Of Indonesia during the period of January 2010 to December 2013. The result of IRF explain that the interest rate channel find the hard way to accomplished the macroeconomic goals while the Islamic monetary instrument indicates the potential growth of output and hold the inflation low. The result of VDC describes that the Islamic instrument still affected by conventional monetary policy because of slow development in Islamic monetary system.
\end{abstract}

Keywords: Dual monetary policy; Macroeconomics; VAR

\begin{abstract}
Abstrak. Sistem Moneter Ganda dan Kinerja Makroekonomi di Indonesia. Penelitian ini bertujuan untuk mengevaluasi dampak kebijakan moneter ganda terhadap indikator makroekonomi di Indonesia yakni pertumbuhan dan inflasi. Sebagai tambahan, penelitian ini juga menguji apakah kebijakan moneter konvensional memiliki dampak khusus terhadap sektor perbankan Islam. Penelitian ini menggunakan metode VAR (vector auto regressive) dengan data bulanan yang bersumber dari Bank Indonesia dari January 2010 sampai Desember 2013. Hasil IRF menjelaskan bahwa jalur suku bunga memiliki kesulitan untuk mencapai target makroekonomi sedangkan instrumen moneter Islam mengindikasikan adanya potensi pertumbuhan output dan menahan laju inflasi. Hasil VDC menggambarkan bahwa instrumen Islam masih dipengaruhi oleh kebijakan moneter konvensional karena lambatnya perkembangan sistem moneter Islam.
\end{abstract}

Kata Kunci: Kebijakan moneter ganda; Makroekonomi; VAR 


\section{Introduction}

Monetary policy is an instrument of the central bank for accomplishing the macroeconomics objective such as the growth of output, price stability, and indirectly affects the unemployment rate. However, it can not be denied that sometimes the implementation of an instrument of monetary policy could potentially produce a wide range of impacts that are not expected (Mishkin, 1995), so, to be successful in conducting monetary policy, the monetary authorities must have an accurate assessment and better understanding of the mechanisms through which monetary policy supports the macroeconomic goals. Indonesia uses the dual monetary system to control the circulation of funds in order to encourage the conventional loan and Islamic financing on variety business sectors. The dual banking system in Indonesia has been formally running since 1998, marked with the promulgation of Act (the ACT) of banking in 1998 and continued with the designation of the banking ACT in 1999, which gives the authority to Bank Of Indonesia (the central bank) to run the dual monetary policy: conventional and Islam.

Conventional monetary policy applied the interest rate in the transmission of monetary policy. However, this action is most likely does not comply with the expectation, because, first, there is trade-off in the implementation of tight and loose monetary policy. Tight monetary policy means there is the potential of low inflation but followed by low output as a result of the higher cost of capital, while the loose monetary policy would bring output growth but it seems that inflation might be accelerate because of the overheated economy. Second, the change of economics agent motives like speculation activity, especially in the trading of derivative products, this case would make the money does not flow enough to the real sectors. In other words, macroeconomic goals are not accomplished.

Instrument of Islamic monetary policy using profit loss sharing, margin, and fee to replace the interest rate system because Islamic economic agent believe that the insterest as Riba component within the transmission of monetary policy. Profit loss sharing (PLS) system has the sense of justice that can be seen when the owners of capital and entrepreneurs work together in running business. If businesses are losing, then the loss will be bear along. Otherwise, if business makes profit then it will be divided according to the agreed ratio/nisbah (Abdullah \& Chee, 2010). Islamic economic insists that the role of money must be able to optimally support the real sector and not making it as a tradable commodity. Therefore, Islamic economic agents are not recommended to play active in derivatives trading that do not involve an underlying assets, according to Islamic economics doctrine that forbid the existence of riba, gambling, and uncertainty in the economic activity.

Banks has a strategic role in allocating funds within the private sector, so, 
the monetary authority should control the activity of their transactions in order to avoid negative impact that generated by such event. Bank Of Indonesia (BI) can do expansionary or contractive monetary policy depend situation within the economy, operationally, the stance of monetary policy is described through the setting of the policy rate which in this case is Bank Indonesia benchmark interest rate (BI Rate). The mechanism of BI Rate to affects the macroeconomic indicators called monetary transmission mechanism, this mechanism using various channels to connect the monetary policy and economy. This paper uses output growth and inflation as the indicators of macro economy because they are the goals of conducting monetary policy. Since BI formally using the Inflation Targeting Framework (ITF) in 2005, the highest level of inflation reachs $13,11 \%$ in 2006, during the same period, the highest economic growth in Indonesia is $6.35 \%$ in 2007. ITF uses BI Rate as benchmark policy to affect the interest rate, this action is expected may keep the inflation target. Dual monetary policiy in Indonesia is not only implementing conventional rate policy that reflected by conventional interbank money market (PUAB), but also uses Islamic policy rate that reflected by Islamic interbank money market (PUAS). PUAB then could affect the level of deposits and credit of conventional bank whereas PUAS affects the level of deposits and financing of Islamic banks. Finally, changes in credit/financing would affect the level of output and inflation.

The research about relationship between monetary policy, output growth, and inflation has been discussed by Fung (2002), Dabla-Norris \& Floerkemier (2006), and Cheng (2006). These researchs just studied the interest-based monetary policy that affect the macroeconomic indicators namely output and inflation but did not discuss the interest-free monetary policy.

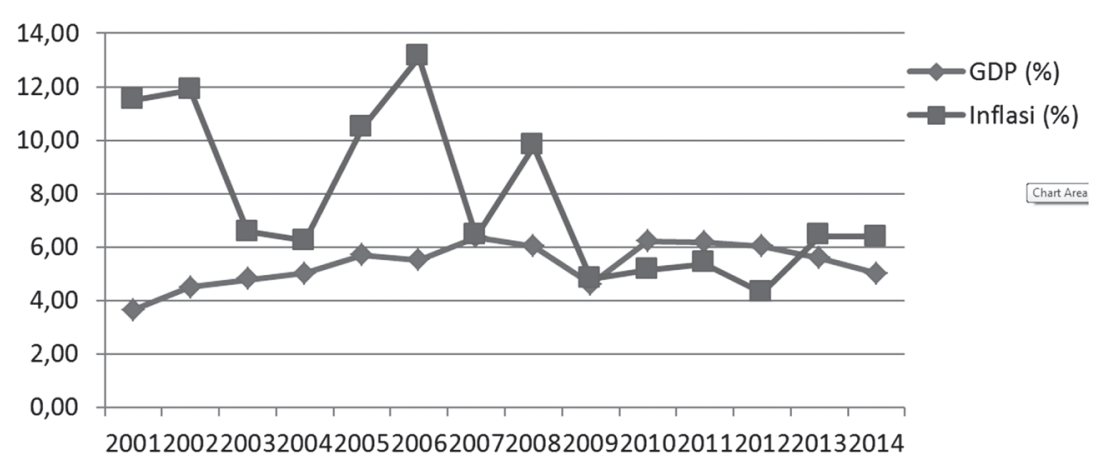

Figure 1. Macroeconomics Performance in Indonesia Source: World Development Indicators 
Unfortunately, it is said by Siddiqui (in Ascarya, 2012) that Islamic monetary development still has no firm concept regard the transmission of monetary policy including its channel. To our knowledge, the idea of PLS as a core of monetary policy is still immature to be applied in the monetary system especially in Indonesia. Therefore, it is become the great need among scholars to empirically prove the effectiveness of Islamic monetary system. In Indonesia's case, because the design is dual monetary system, it is important to measure how the changes in conventional and Islamic monetary policy could impact the macroeconomics indicator. Based on these thought, this research aims to evaluate how the instruments of dual monetary policy could affect the macroeconomic indicators of Indonesia: growth and inflation. In addition, this study will also examine whether conventional monetary policy has a particular impact against Islamic banking sector. The second session of the study discusses the study of literature, the third session discusses the methodology, fourth session discusses the results, while the conclusion will be presented in the fifth session.

\section{Literature Review}

The mechanism of conventional monetary transmission describes how policy changes in short-term nominal interest rates impact the real variables such as output and unemployment. Specific channels of monetary transmission operate through the effects that monetary policy has on interest rates, exchange rates, equity and real estate prices, bank lending, and firm balance sheets (Ireland, 2005). Monetary policy transmission in Indonesia that conducted via interest rate became the major issue in this discussion. One of the founders of contemporary Islamic monetary economics named Chapra (in Ascarya, 2012) did not describe specifically about the transmission policy. Therefore, to examine the effectiveness of Islamic monetary policy, some researchers adopt the concept of interest rates channel with equivalent modification.

Naveed (2015) suggested that the conventional banks are more sensitive to interest rate, while the Islamic bank did not get such impact. Interest rate did not make high impact against Islamic banks because Islamic banks are not using interest rate in their system. However, conventional banks are more stable than Islamic banks because they have higher amount of capital. According to the results of Variance Decomposition Analysis, monetary policy had no effect on the level of Islamic banks deposits. Only about $1 \%$ of the changes at the level of the Islamic bank deposits accounted for the impact of the monetary policy rate changes, while deposits and conventional loan are affected by the ONR (Overnight Rate) by $10 \%$ and $6 \%$. Interesting thing here is the financing of Islamic banks are also affected 
by the ONR amounted to $6 \%$. This suggests that conventional instruments also indirectly might affect the Islamic instruments.

Kassim (2009) found the result that contrary to the general expectations, the result show that the Islamic banks are relatively more sensitive to monetary policy changes, while the conventional banks items, particularly the conventional loan, are insensitive to the interest rate changes. This implies that the impact of monetary policy is more destabilizing on the Islamic banks than the conventional. The result of the study have important implications for the risk management practices of the Islamic banks, specially in dual banking system such as in Malaysia. Hakan and Gulumser (2011) explained in their research that the changes in interest rate not only affect to the conventional deposit and loan, but it affects the Islamic bank instruments too. This study shows that interest rate could negatively impact on Islamic deposit because the raise of interest rate would divert the attention of the third party so they prefer to deposit their money in conventional bank rather than Islamic banks. This research disproving the arguments claiming that Islamic banks are more stable than conventional bank just because their product is interest-free and the claim that said Islamic banks could gave positive contributions to achieve finance stability.

Those previous studies just provide the information about the impact of monetary policy against the Islamic and conventional banks, while the research about the impact on macroeconomic indicator is started by Sukmana and Kassim (2010). The macroeconomic indicator is economic growth and the research method using VAR model with the following:

$$
\mathrm{IPI}=f(\mathrm{IF}, \mathrm{ID}, \mathrm{ONIGHT})
$$

IPI (Industrial production index) is a proxy of economic growth, IF is the financing of Islamic bank, ID is third party funds in Islamic bank, and ONIGHT is the overnight interest rate in the conventional interbank money market as an indicator of monetary policy.

Ascarya (in Ascarya, 2012) did the same thing by using Islamic instruments and macroeconomic indicators namely economic growth and inflation. Research methods using VAR model as follows:

$$
\begin{aligned}
& \text { IPI }=f(\text { IFIN }, \text { IDEP,PUAS,SBIS }) \\
& \text { CPI }=f(\text { IFIN,IDEP,PUAS,SBIS })
\end{aligned}
$$

IPI is used as proxy of economic growth, CPI (Consumer price index) as proxy for inflation, IFIN is financing of the Islamic banks, IDEP is third party funds in Islamic banks, PUAS is the Islamic interbank money market, and SBIS is Islamics certificate of Bank Indonesia. 


\section{Methods}

To analyze the impact of dual monetary policy against macroeconomic performance, then this study adapt the research model of Sukmana \& Kassim (2010) and Ascarya (2010). The macroeconomics indicators are output (Industrial Production Index) and inflation (Consumer Price Index). Source of the data is from Bank Indonesia: January 2010 - December 2013. Equation (4), (5) and (6) are used as research model 1,2 , and 3 .

$$
\begin{aligned}
& \mathrm{PI}=f(\mathrm{CD}, \mathrm{CL}, \mathrm{ID}, \mathrm{IF}, \mathrm{PB}, \mathrm{PS}) \\
& \mathrm{CPI}=f(\mathrm{CD}, \mathrm{CL}, \mathrm{ID}, \mathrm{IF}, \mathrm{PB}, \mathrm{PS}) \\
& \mathrm{PS}=f(\mathrm{BR}, \mathrm{CD}, \mathrm{CL}, \mathrm{ID}, \mathrm{IF}, \mathrm{PB})
\end{aligned}
$$

Dual monetary policy instruments for this study are conventional interbank money market and Islamic interbank money market that represent conventional and Islamic monetary policy. We believe that choosing interbank money market as proxy for monetary policy is still fairly compatible eventough other studies are using conventional and Islamic BI's certificate. The reasons for choosing interbank money market are because it considerably relevant with deposits interest rate, reflected the condition of money market, and it may be affected by open market (Warijoyo and Zuverdi, 1998). Meanwhile the reason for choosing the BI certificate is to reach the base money target (Ramayandi \& Rosario, 2010).

These policies would drive the rate of conventional bank deposits, conventional bank loans, Islamic bank deposits, and Islamic bank financing, then finally impact the level of output and inflation. In addition, the study also examined whether conventional monetary policy, i.e. BI rate has a particular impact against Islamic banking. Variables are transformed into the natural logarithm $(\mathrm{Ln})$ except for variables that already in the units of percent $(\%)$.

Table 1. List of Variables

\begin{tabular}{cccc}
\hline Variable & Definition & Variable & Definition \\
\hline CD & $\begin{array}{c}\text { Convensional } \\
\text { Deposits }\end{array}$ & BR (\%) & BI Rate \\
CL & Convensional Loan & PB (\%) & Conventional interbank money market \\
ID & Islamic Deposits & PS (\%) & Islamic interbank money market \\
& & CPI & Consumer Price Index \\
IF & Islamic Financing & IPI & Industrial Production Index \\
\hline
\end{tabular}




\section{Results and Discussion}

\section{Unit root test}

The technique of testing method using ADF (Augmented Dickey-Fuller), the length of the lag are automatically selected based on SIC (Schwartz Information Criterion) with maximum lag of 9. Test results in Table 2 shows that most of the variables are not stationary at I (0). Therefore, this model can be extended on the model of estimation of VAR I (1) or VECM in accordance with the test results of the Cointegration test.

Table 2. ADF Test Results

\begin{tabular}{cccccc}
\hline \multicolumn{5}{c}{ ADF test results } \\
\hline Series & Level & First Difference & Level & First Difference \\
& Prob. & Prob. & Series & Prob. & Prob. \\
CD & $0.0120^{* *}$ & $0.0000^{* * *}$ & CPI & 0.9173 & $0.0000^{* * *}$ \\
CL & 0.9508 & $0.0000^{* * *}$ & BR & 0.9417 & $0.0098^{* * *}$ \\
ID & 0.1954 & $0.0000^{* * *}$ & PB & 0.9995 & $0.0767^{*}$ \\
IF & 0.5634 & $0.0632^{*}$ & & & \\
IPI & $0.0013^{* * *}$ & $0.0000^{* * *}$ & PS & $0.0056^{* * *}$ & $0.0000^{* * *}$ \\
\hline
\end{tabular}

*ignificant at $10 \%{ }^{* *}$ significant at $5 \%{ }^{* * *}$ significant at $1 \%$

\section{Cointegration Test}

Cointegration is defined to exist if two or more series are linked to form an equilibrium long run relationship, eventhough the series themselves may contain stochastic trends (non-stationary). They will nevertheless move closely together over time and difference between them will be stable (Harris, 1995). The Johansen Cointegration Test is a technique to find out the longterm relationship between variables. Test results that based on Trace Statistics suggest that the three of research model has cointegrated variables at least in one rank at the level of 5\% significance. Thus, due to the existence of cointegration 
Al-Iqtishad: Jurnal Ilmu Ekonomi Syariah (Journal of Islamic Economics) Vol. 8 (1), January 2016

relationship within variable then estimation technique will be extended to the VEC model.

\section{Impulse Response Function and Variance Decomposition}

Model 1 and 2 use the IRF analysis to answer the impact of dual monetary policy shock against macroeconomic indicator, while model 3 uses the VDC analysis to invetigate the particular impact of conventional monetary policy against the Islamic variable.

IRF result for model 1 (LnIPI) illustrates that the conventionals variables shock do not always get positive response by variable output. PB has negative impact to output in the $2^{\text {nd }}$ period then return to the equilibrium in the $6^{\text {th }}$ period and then increasing output at the next period. CD affects the raise of output in the $2^{\text {nd }}$ period but otherwise in the $4^{\text {th }}$ period, CD affects the raise of output again after back at the equilibrium in the $6^{\text {th }}$ period. CL only has positive impact upon output in the $2^{\text {nd }}$ period, then return to equilibrium in the $3^{\text {rd }}$ period and subsequent impact on the decreasing output. Meanwhile, compared to conventional factor, the shocks of Islamics variables consistently get the positif response by the level of output. Impact of ID and IF to the ouput growth can be seen in the $3^{\text {rd }}$ and $2^{\text {nd }}$ period after moving along in the equilibrium point. On the other hand, the level of ouput has positif response to variable PS because PS is not based on interest rate but it based on profit loss sharing of IMA's certificate (Interbank Mudharabah Investment).

Table 3. Johansen Cointegration Test Result

\begin{tabular}{ccccc}
\hline \multicolumn{5}{c}{ Model 1 } \\
\hline Hypothesized & & \multicolumn{2}{c}{ Trace } \\
& Eigenvalue & Statistic & Critical Value & Prob.** \\
None ${ }^{*}$ & 0.878517 & 254.4989 & 139.2753 & 0.0000 \\
At most $1 *$ & 0.749319 & 161.7476 & 107.3466 & 0.0000 \\
At most 2* & 0.675954 & 100.8703 & 79.34145 & 0.0005 \\
At most 3 & 0.436729 & 51.28807 & 55.24578 & 0.1068 \\
\hline
\end{tabular}




\begin{tabular}{ccccc}
\hline \multicolumn{5}{c}{ Model 2 } \\
\hline Hypothesized & Eigenvalue & Statistic & Critical Value & Prob.** $^{* *}$ \\
& 0.919880 & 331.6028 & 139.2753 & 0.0000 \\
None ${ }^{*}$ & 0.853455 & 220.5369 & 107.3466 & 0.0000 \\
At most 1* & 0.699732 & 136.0383 & 79.34145 & 0.0000 \\
At most 2* & 0.619692 & 83.10271 & 55.24578 & 0.0000 \\
\hline At most 3* & & &
\end{tabular}

Model 3

\begin{tabular}{ccccc}
\hline Hypothesized & \multicolumn{4}{c}{ Trace } \\
& Eigenvalue & Statistic & Critical Value & Prob. $^{* *}$ \\
None & 0.878193 & 279.6831 & 139.2753 & 0.0000 \\
At most 1 & 0.747734 & 187.0492 & 107.3466 & 0.0000 \\
At most 2* & 0.673949 & 126.4492 & 79.34145 & 0.0000 \\
At most 3 & 0.575922 & 77.13843 & 55.24578 & 0.0002 \\
\hline
\end{tabular}

** significant at 5\%

IRF result for model 2 (lnCPI) describes that the shock of conventional variable which get negative response by the level of inflation is variable $\mathrm{CD}$ only, whereas PB and CL have positive response. In other words, PB and CL cause the raise of general price while $\mathrm{CD}$ could decrease the level of inflation in the $8^{\text {th }}$ period. Raising the interest rate is a reflection of tight monetary policy that makes the cost of capital become more expensive, signaling higher price, then accelerates inflation. Unlike the conventional variable, shocks of Islamic instruments have negative response from inflation. PS, ID, and IF could decrease inflation in the $4^{\text {th }}, 2^{\text {nd }}$, and $2^{\text {nd }}$ period. Islamic interbank money market affects the level of Islamic deposit and financing, than this action would impact the composition of Islamic bank financing. Funds that distributed by Islamic banks use the PLS system, this system keep the output production from the high cost of capital that drived by interest rate and finally gave some contribution to restrain the level of inflation. 
Al-Iqtishad: Jurnal Ilmu Ekonomi Syariah (Journal of Islamic Economics) Vol. 8 (1), January 2016

Accumulated Response to Cholesky One S.D. Innovations

Accumulated Response of LOG(IPI) to PB

Accumulated Response of LOG(IPI) to PS
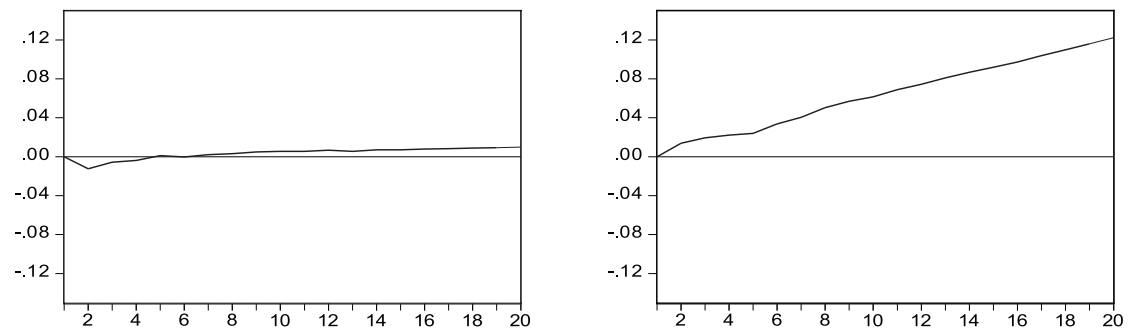

Accumulated Response of LOG(IPI) to LOG(CD)

Accumulated Response of LOG(IPI) to LOG(ID)
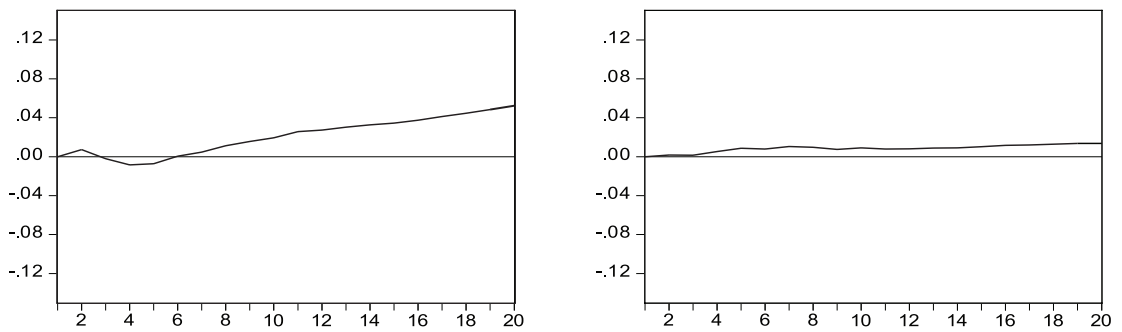

Accumulated Response of LOG(IPI) to LOG(CL)

Accumulated Response of LOG(IPI) to LOG(IF)
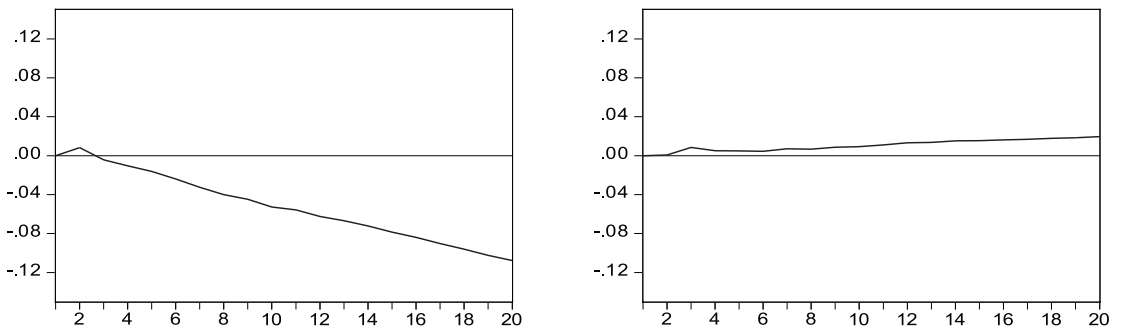

Figure 2. IRF Model 1

The result of VDC shows that the PS is dominantly affected by itself in the $1^{\text {st }}$ period and than continue to fall until $20^{\text {th }}$ periode but it still dominant by itself. In the $6^{\text {th }}$ period, the effect of BR starting to show as a variable that has particular impact upon PS and keep slowly going up until the $20^{\text {th }}$ period with maximum value of $11,67 \%$. This condition describe that PS is affected by conventional instrument i.e BI Rate. Conceptually, BI rate should not affect the Islamic variable because it is an interest-based instrument. However, practically, BI rate is the benchmark for the rate of PS. Therefore, Islamics monetary instrument yet can not be said free from conventionals policy. 

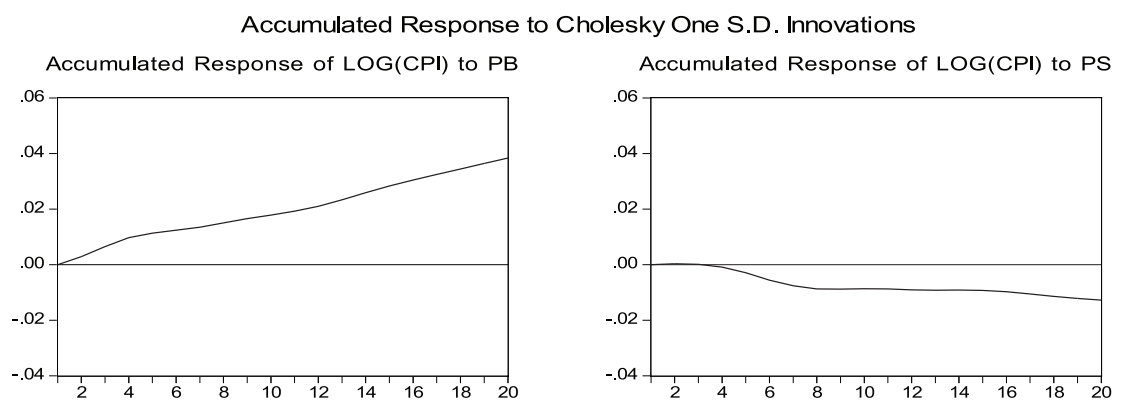

Accumulated Response of LOG(CPI) to LOG(CD)

Accumulated Response of LOG(CPI) to LOG(ID)
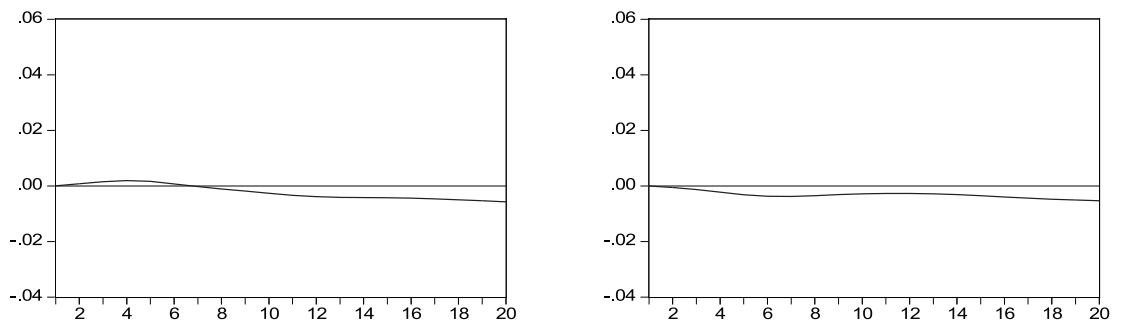

Accumulated Response of LOG(CPI) to LOG(CL)

Accumulated Response of LOG(CPI) to LOG(IF)
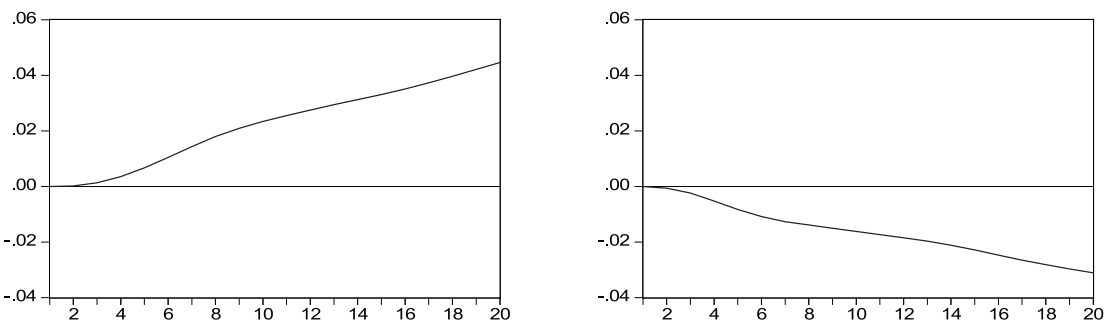

Figure 3. IRF Model 2

\section{Some Lessons from Dual Monetary}

The goal of monetary policy is to fulfill the macroeconomic objectives such as output growth, price stability, and indirectly affects the unemployment rate. In order to achieve these goals, monetary authority uses interest rate as core design for conducting the policy. However, it requires accurate information to decide between tight and loose monetary policy that could comply with those monetary objectives. There are some suggestions that interest rates do not play the central role that they do in traditional monetary theories. The interest rate is not like conventional price, but it is looks like a "promise" between lenders and borrowers to pay an amount in the future. Promises are often broken, if they are not, there would be no issues in 
determining the credit worthness. Credit is not primarily allocated via something like an auction market but allocated by system of which potential lenders make judgements about the risk associates with various borrowers (Greenwald and Stiglitz, 2003). Meanwhile, the Islamic monetary policy suggest PLS system that could control the economics because money does not generate itself but it increase or accumulates, justifiably, through "actual" investment in accordance with various Islamic modes/akad of investment (El-Ghazali, 1994).

Impact of conventional monetary policy against the growth of output in this study shows that the interest rate channel has low contribution on the level of output. The rate of interbank money market is influenced by BI Rate. The range of BI Rate between 6,5\%-7,5\% from 2010-2013 reflects the implementation of tight monetary policy that aims to achieve the price stability but could not highly increase the level of output, when the impulse is interbank money market, the response of output is slightly positive. Growth in output is the result of improving variety of resources, one of which is financed by the capital savings, so, higher cost of capital that drived by interest rate would not highly increase the level of output. The result also shows that conventional monetary policy accelerates the level of inflation, it could be said that the more interest-based loan circulate within economy, the more it raises inflation. Meanwhile, Islamic monetary policy has positive relationship with the level of output. Islamic interbank money market is not interest-based instrument but based on interbanks profit-loss sharing, so, it is not only could increase the level of output but also hold the inflation. According to Islamic principle, the cost of capital lies in the profit of projects investement. On the other hand, share in the profit is the cost of capital (El-Ghazali, 1994). So the "promise" between lenders and borrowers is not to pay an amount in the future like interest rate, but to share the profit and loss according to their contract. However, it can not be denied that Islamic banks only have 5\% market share with below 10 million of customers, so, they still have a long way to go to become the main focus of monetary policy. VDC analysis shows the obvious result that Islamic monetary instrument yet can not be said free form conventional influence, it is because the monetary policy design is based on interest rate that represented by BI rate, so the Islamic instrument has to follow that stance.

The result is slightly different with Banjarnahor (2008), Anuniyyah et al (2010), Anuniyyah et al (2013), Ascarya (2012), and Sanrego (2013). Eventough we did not employ SBI and SBIS as we explained earlier, our finding is fairly consistent with those previous study, these researchs show that conventional monetary has positive relationship with inflation while Islamic monetary has 
negative relationship. On the other side, Anuniyyah et al (2010) and Anuniyyah et al (2013) employed SBIS as their proxy for Islamic monetary instrument but this study is not. Their result shows that SBIS is unable to support the growth of output because it is used just as an instrument of absorbing the idle fund that did not allocated to the real sector financing, while this study shows that Islamic monetary proxied by Islamic interbank could increase the output because that idle fund is allocated (with Islamic akad) to the other banks so the fund could be injected to real sector.

\section{Conclusion}

Monetary policy is an instrument of the central bank for accomplishing the macroeconomics objective such as the growth of output, price stability, and indirectly affects the unemployment rate. The result of IRF explain that the interest rate channel find the hard way to accomplish the macroeconomic goals while the Islamic instrument indicates the potential growth of output and holding the inflation low. Interest rate would raise the cost of capital, signaling the higher price, and lower output. Islamic instrument uses the profit loss sharing system, this system keep the output production from the high cost of capital that drived by interest rate. The result also shows that Islamic monetary instrument yet can not be said free form conventional influence because the monetary policy design is based on interest rate that represented by BI rate, it disproving the claim that Islamic banks are not affected with interest-based policy instrument. This condition occurs because conventional banks are the old players that have higher market share than Islamic banks. Those findings empirically conclude that, compared to conventional monetary, Islamic monetary policy could fulfill the macroeconomics goals: growth of output and low inflation.

The results show that Islamic monetary is fairly more relevant to achieve macroeconomic goals. So the monetary authority should have more attention to development of Islamic monetary, like trying to slowly reduce the domination of interest-based instrument e.g SBI or conventional interbank money market, encourage the Islamic instruments, and convince the government to shift part of their deposit from conventional to Islamic banks, because, the greater chances is what the Islamic monetary need to make a room for its improvement and achieving macroeconomic objectives. Monetary authority also may reduce using SBI/SBIS to absorb the funds, but keep them circulate enough through financing to produce goods and service instead generate them through bonus (SBIS) and interest (SBI). 
We believe that there are some limitations in this research because it must be another Islamic instrument beside Islamic interbank money market and another control variable that could reflect the condition of Indonesia's macro economy. So it would be usefull for the future research to find more comprehensive discussion regarding Islamic monetary.

\section{References}

Abdullah, D.V. \& Chee. K. (2010). Buku Pintar Keuangan Syariah. Jakarta: Zaman. Anuniyyah, Q, et.al. (2010). Analisis Pengaruh Instrumen Moneter Syariah Dan Konvensional Terhadap Pertumbuhan Sektor Riil Di Indonesia. Iqtisodia, Jurnal Ekonomi Islam Republika, pp. 6.

Anuniyyah, Q, et.al. (2013). Dynamic Analysis Of Islamic Bank And Monetary Instrument Towards Real Output And Inflation In Indonesia. Proceeding Of Sharia Economics Conference, Hannover, pp. 154-162.

Ascarya. (2012). Alur Transmisi Dan Efektifitas Kebijakan Moneter Ganda Di Indonesia. Buletin Ekonomi Moneter dan Perbankan, Vol. 14, No. 3, hlm. 283-315.

Asteriou, D. \& Hall, S. G. (2007). Applied Econometrics: A Modern Approach. Revised Edn. New York: Palgrave Macmillan.

Banjarnahor, N. R. (2008). Mekanisme Suku Bunga SBI sebagai Sasaran Operasi Kebijakan Moneter dan Variabel Makroekonomi Indonesia: 1990.1-2007.4. Buletin Ekonomi Moneter dan Perbankan, pp. 22-51.

Cheng, K.C. (2006). A VAR Analysis of Kenya's Monetary Policy Transmission Mechanism: How Does the Central Bank's REPO Rate Affect the Economy? IMF Working Paper No. 300 pp. 1-28.

Dabla-Norris, E. \& Floerkemier, H. (2006). Transmission Mechanisms of Monetary Policy in Armenia: Evidence from VAR Analysis. IMF Working Paper No. 248, pp 1-29.

El-Ghazali, A. H. (1994). Profit Versus Bank Interest In Economic Analysis And Islamic Law. Islamic Economics Translation. Jeddah: IDB-IRTI.

Enders, W. (2004). Applied Econometric Time Series. New York: John Wiley \& Sons.

Ertürk, M. \& Yüksel, S. (2013). Casual Link Between Islamic And Conventional Banking: Evidence From Turkish Banking Sector. Research Department Of Borsa Istanbul, Working Paper Series, No. 6, pp. 1-20. 
Fung, B. S. C. (2002). A VAR Analysis of the Effects of Monetary Policy in East Asia. BIS Working Papers No. 119, pp 1-23.

Greenwald, B. \& Stiglitz, E. J. (2003). Toward A New Paradigm In Monetary Economics. United Kingdom: Cambridge University Press.

Hakan, E.E. \& Gulumser, A.B. (2011). Impact Of Interest Rates On Islamic And Conventional Banks: The Case Of Turkey. MPRA Paper No. 29848, pp. 1-18.

Haron, S. \& Ahmad, N. (2000). The Effects Of Conventional Interest Rates And Rate Of Profit On Funds Deposited With Islamic Banking System In Malaysia. International Journal of Islamic Financial Services, Vol. 1, No. 4, pp. $1-7$.

Ireland, N. P. (2005). The Monetary Transmission Mechanism. Federal Reserve Bank of Boston, No. 06-1, pp. 1-13.

Kassim, S.H. (2009). Impact Of Monetary Policy Shocks On The Conventional And Islamic Banks In A Dual Banking System: Evidence From Malaysia. Journal Of Economic Cooperation And Development, Vol. 30, No. 1, pp. 41-58.

Kasri, R. \& Kassim, S. (2009). Empirical Determinants Of Saving In The Islamic Banks: Evidence From Indonesia. Jkau, Islamic Econ, Vol. 22, No. 2, pp. 181-201.

Mishkin, F.S. (1995). Symposium On The Monetary Transmission Mechanism. Journal Of Economics Perspectives, Vol. 9, No. 4, pp. 3-10.

Naveed, M.Y. (2015). Impact Of Monetary Policy Shocks In A Dual Banking System In Pakistan: A Vector Auto Regressive Approach. European Academic Research Vol. 1i, Issue 11, pp. 14684-14700.

Pesaran, M.H. \& Shin, Y. (1998). Generalized Impulse Response Analysis In Linear Multivariate Models. Economic Letters, Vol. 58, pp. 17-29.

Ramayandi, A. \& Rosario, A. (2010). Monetary policy Discipline and Macroeconomics Performance: The Case of Indonesia. ADB Economics WP Series No. 238, pp 1-31.

Sanegro, Y. D. \& Rusydiana, A.S. (2014). Transmission Mechanism In Dual Monetary System: Comparison Between Shariah And Conventional Monetary System. Journal Of Islamic Economics, Banking, And Finances, Vol. 9, No. 2, pp. 27-44.

Sukmana, R. \& Kassim, S. H. (2010). Roles of The Islamic Banks In The Monetary Transmission Process In Malaysia. International Journal Of Islamic And Middle Eastern Finance And Management, Vol. 3, No. 1, pp 7-19. 
Al-Iqtishad: Jurnal Ilmu Ekonomi Syariah (Journal of Islamic Economics) Vol. 8 (1), January 2016

Warijoyo, P. \& Zuverdi, D. (1998). Penggunaan Suku Bunga Sebagai Sasaran Operasional Kebijakan Moneter Di Indonesia. Buletin Ekonomi Moneter dan Perbankan, pp 25-53. 